\title{
PENGARUH ELEKTRONIK WORD OF MOUTH DAN BRAND IMAGE TERHADAP PURCHASE INTENTION PADA KONSUMEN SMARTPHONE SAMSUNG YANG BERBASIS ANDROID
}

\author{
Arif Wibowo, MEI, \\ Email: arif_wibowo@uny.ac.id \\ Jurusan Manajemen Fakultas Ekonomi, Universitas Negeri Yogyakarta
}

\begin{abstract}
Abstrak
Penelitian ini bertujuan untuk menganalisis Pengaruh Elektronik Word Of Mouth dan Brand Image Terhadap Purchase Intention Pada Konsumen Smartphone Samsung Yang Berbasis Android. Penelitian ini termasuk penelitian yang dikategorikan kedalam penelitian pengujian hipotesis. Populasi dari penelitian ini adalah mahasiswa S1 di Fakultas Ekonomi Universitas Negeri Yogyakarta yang menggunakan smartphone android. Teknik pengumpulan data menggunakan kuesioner yang menggunakan metode self-administered survey. Peneliti mengambil sampel 100 mahasiswa S1 Fakultas Ekonomi Universitas Negeri Yogyakarta, yang menggunakan smartphone Samsung yang berbasis android. Pengambilan sampel dalam penelitian ini menggunakan nonprobability sampling. Teknik analisis yang digunakan adalah menggunakan uji validitas reliabilitas, korelasi, regresi berganda, dan uji hipotesis dengan menggunakan program SPSS versi 22.

Hasil penelitian berdasarkan regresi berganda menunjukkan bahwa : (1) elektronik word of mouth berpengaruh positif pada purchase intention pada konsumen smartphone Samsung yang berbasis android dengan koefisien sebesar 0,327. (2) Brand image berpengaruh positif terhadap purchase intention pada konsumen smartphone Samsung yang berbasis android dengan koefisien sebesar 0,278.

Keywords : Elektronik word of mouth (EWOM), brand image, purchase intention, smartphone Samsung berbasis android.

\section{Latar Belakang}

Seiring dengan perkembangan teknologi, telekomunikasi di Indonesia yang mengalami kemajuan yang sangat pesat, pilihan konsumen akan barang dan jasa semakin beragam jenisnya. Dengan segala keunikan, manfaat, dan kualitasnya, tentunya akan semakin sulit bagi konsumen dalam mengambil keputusan

guna memilih barang atau jasa mana yang terbaik dan tepat untuk mereka. Untuk dapat mengambil keputusan pembelian tersebut, satu-satunya cara yang dapat dilakukan konsumen adalah dengan mencari informasi sebanyak-banyaknya akan barang atau jasa tersebut. Tidak cukup dengan informasi yang banyak, tapi informasi tersebut haruslah dapat
\end{abstract}


dipercaya kebenarannya. Salah satu sumber informasi yang memenuhi syarat tersebut adalah komunikasi dari mulut ke mulut atau lebih dikenal dengan sebutan WOM atau Word of Mouth.

Semakin maraknya produk-produk android saat ini, konsumen banyak yang beralih dari menggunakan handphone menjadi smartphone android. Smartphone memang memiliki banyak kelebihan dan daya tarik tersendiri dibandingkan dengan handphone biasa. Salah satu yang paling menonjol dari kelebihan smartphone android adalah fungsinya yang lebih luas, kecepatan dan kemampuan browsing internet yang cepat membuat para pengguna perangkat ini bisa tetap terhubung dengan dunia maya ataupun sosial media dimanapun dan kapanpun dengan lebih cepat dan mudah.

Smartphone Samsung android sangat diminati oleh konsumen karena konsumen percaya akan produk tersebut baik dari merek, dan harga tidak pernah menipu bahwa Samsung benar-benar menonjolkan kualitas dengan gambarnya yang sangat jernih, fitur-fiturnya yang sangat banyak. Dengan berbagai fitur sosial media, hiburan, fitur-fitur lain yang sangat lengkap. Konsumen biasanya juga mempertimbangkan suatu produk tersebut dari bentuk, spesifikasi, desain, daya tahan dari produk itu sendiri. Terkadang konsumen mecari referensi mengenai suatu produk yang akan dibelinya baik itu dari internet atau dari teman yang telah terlebih dahulu menggunakan produk tersebut. Hal ini terjadi karena konsumen ingin mencari produk yang dapat memberikan kemudahan berkomunikasi dalam beraktivitas sehari-hari.

Di antara sekian banyak produk smartphone Android yang beredar dipasaran, Samsung merupakan salah satu smartphone yang mengikuti perkembangan teknologi dan memenuhi kebutuhan konsumen. Samsung sangat diminati oleh konsumen karena memiliki fitur-fitur yang memberikan kemudahan bagi pengguna dalam membuka atau mengirim email, mengakses website, chatting menggunakan aplikasi whatsapp, line, BBM, kakaotalk, dan lain-lain, dapat digunakan untuk mengakses jejaring sosial seperti facebook, twitter, path, dan sebagainya. Konsumen mengetahui keberadaan smartphone Samsung dari berbagai sumber informasi yaitu dari teman-teman yang telah menggunakan, iklan di televisi, brosur, radio dan internet. Konsumen juga lebih suka mencari review terlebih dahulu di internet sebelum membeli produk smartphone Samsung dari internet baik membuka forum-forum, membaca majalah. Setelah yakin dengan pilihannya maka konsumen akan memutuskan untuk melakukan pembelian. 
Jika melihat ke belakang komunikasi dari mulut ke mulut hanya bisa digunakan secara langsung (tatap muka). Namun, seiring dengan perkembangan teknologi informasi yang sangat cepat, pertukaran informasi antar konsumen tidak lagi dilakukan dengan tatap muka tetapi juga bisa dilakukan melalui internet. Melalui internet Word of Mouth tidak lagi hanya bisa dilakukan oleh beberapa orang tetapi saat ini juga bisa dilakukan oleh semua orang di semua penjuru dunia tanpa batas.

Dengan adanya fenomena tersebut, akhirakhir ini mulai muncul apa yang disebut Electronic Word of Mouth (EWOM). EWOM sendiri didefinisikan sebagai pernyataan positif atau negatif yang dibuat oleh konsumen potensial, konsumen yang telah beralih ke produk lain, konsumen yang setia dengan produk yang di keluarkan oleh perusahaan tertentu.

Menurut Henning - Thurau et al. 2004), e - WOM adalah komunikasi positif atau negatif antara potensi, pelanggan atau mantan tentang produk atau perusahaan yang tersedia untuk umum di internet . Memang, beberapa studi penelitian terbaru telah meneliti e - WOM dan mengklaim bahwa dampaknya tidak seefektif tradisional face -to-face dari mulut ke mulut (Sen dan Lerman , 2007) dan sulit untuk mengukur dampak pada laba atas investasi (Ferguson, 2008). Sebaliknya, Steffes dan Burgee (2009) menemukan bahwa informasi yang diperoleh dari forum $e$ - WOM lebih berpengaruh dalam pengambilan keputusan daripada berbicara dengan teman-teman secara pribadi ( WOM ). Meskipun ada bukti yang bertentangan pada kredibilitas e - WOM, studi yang dilakukan sampai saat ini tidak mempertimbangkan jenis sumber informasi online yang digunakan dan efektivitas mereka. Hal ini semakin mungkin bahwa meningkatnya jumlah review dan pendapat situs online yang memungkinkan konsumen untuk membuat keputusan berdasarkan informasi yang diberikan oleh konsumen yang telah memiliki pengalaman dengan produk, perusahaan, merek atau layanan pelanggan.

Di Indonesia sendiri dengan kultur masyarakat Indonesia yang cenderung senang bersosialisasi, dapat dikatakan situs jejaring sosial menjadi tempat paling baik untuk perkembangan e-WOM. Bukan hanya sebagai ajang pencarian pertemanan saja, tetapi situs jejaring sosial adalah tempat yang paling efektif dan efisien untuk mencari atau menyebarkan informasi. Tulisan-tulisan di situs jejaring sosial saat ini tidak hanya mengenai kehidupan mereka pribadi saja tetapi juga mengenai informasi penting tentang suatu produk tertentu, dari yang hanya berupa tanggapan negatif atau positif terhadap produk tersebut, sampai informasi mengenai review yang sangat detail dari 
suatu produk. Tulisan-tulisan yang mereka unggah lewat internet akan dibaca, dikomentari bahkan bisa diteruskan kepada pencari informasi lainnya mengenai produk tertentu melalui situs jejaring sosial tersebut merupakan salah satu bentuk penting dari komunikasi $e$ WOM. Menurut Lee at al., (2008) dalam Chan dan Ngai (2011), orang-orang biasanya mengandalkan informasi atau pendapat dari pengguna lain yang didapat secara online, bahkan ketika mereka melakukan keputusan offline. Senecal dan Nantel (2004) juga menemukan bahwa konsumen yang menggunakan rekomendasi produk dari konsumen lain secara online, memilih produk yang direkomendasikan dua kali lebih sering dibandingkan dengan konsumen yang tidak menggunakan menggunakan rekomendasi dari manapun. Pada akhirnya, belakangan ini konsumen sudah semakin terbiasa melihat atau mencari produk review secara onlineketika mereka mengumpulkan informasi mengenai suatu produk sebelum mereka melakukan keputusan pembelian. (Zhu dan Zang, 2010) dan dari situlah kemudian terbentuk minat beli dari konsumen atau biasa disebut sebagai purchase intention.

Tidak hanya berimbas pada purchase intention seperti pada penjelasan diatas $e$ WOMternyata juga dapat berimbas pada brand image. Brand Image sendiri didefinisikan sebagai gambaran batin secara keseluruhan yang konsumen sendiri mempunyai suatu merek tersebut serta keunikan dari merek merek itu sendiri dibandingkan dengan merek lain (Faircloth, 2005).

Keller dan Webster (2004) menyatakan, brand image terdiri dari berbagai atribut dan manfaat yang menempel atau terkait pada sebuah merek dan membuat merek tersebut menjadi khas sehingga akan membedakan perusahaan tersebut dengan perusahaan lain dalam kompetisi. Dari pernyataan tersebut dapat disimpulkan kembali bahwa dengan segala fitur dan kelebihannya Samsung berhasil membangun brand image tersendiri di benak konsumen sebagai smartphone berbasis android yang sesuai dengan kebutuhan masyarakat yang senang bersosialisasi seperti yang telah di jelaskan sebelumnya.

Berdasarkan data yang di peroleh dari www.topbrand-award.com menunjukkan bahwa Samsung menjadi salah satu produk yang memiliki Top Brand nomer tiga pada tahun 2013 dengan jumlah presentase sebesar 11,1 persen di dalam tabel Top Brand Index (TBI) seperti yang dapat dilihat di Tabel 1 
Tabel 1

Top Brand Index Smartphone 2013

\begin{tabular}{|l|l|l|}
\hline Merek & TBI & TOP \\
\hline Blackberry & $39,0 \%$ & TOP \\
\hline Nokia & $37,0 \%$ & TOP \\
\hline Samsung & $11,1 \%$ & TOP \\
\hline Nexian & $3,6 \%$ & \\
\hline iPhone & $2,0 \%$ & \\
\hline Cross & $1,9 \%$ & \\
\hline \multicolumn{2}{|c|}{ Sumber : www.topbrand-awardcom } \\
\hline
\end{tabular}

Berdasarkan tabel nomor 2, Samsung mengalami peningkatan penjualan sebesar 18 persen pada tahun 2014. Dibandingkan dengan tahun sebelumnya Samsung hanya menunjukkan tingkat penjualan sebesar 11,1 persen. Hal ini mengindikasikan keberhasilan Samsung dalam menarik minat beli konsumen terhadap produknya. Menurut Tylor (1994), minat beli adalah tahap kecenderungan responden untuk bertindak sebelum keputusan membeli benar-benar dilaksanakan.

\section{Tabel 2}

\section{Top Brand Index Smartphone 2014}

\begin{tabular}{|l|l|l|}
\hline Merek & TBI & TOP \\
\hline Blackberry & $44,3 \%$ & TOP \\
\hline Nokia & $22,7 \%$ & TOP \\
\hline Samsung & $18,0 \%$ & TOP \\
\hline iPhone & $4,3 \%$ & \\
\hline Sony Ericsson & $3,3 \%$ & \\
\hline Nexian & $2,2 \%$ & \\
\hline Cross & $1,6 \%$ & \\
\hline
\end{tabular}

Sumber : www.topbrand-awardcom

\section{Rumusan Masalah}

Berdasarkan penjelasan latar belakang masalah yang diuraikan diatas berkaitan dengan perkembangan teknologi dan terus berkembangnya penggunaan internet di Indonesia, maka elektronik word of mouth mempunyai peran penting dalam mendorong minat beli konsumen pada smartphone samsung dan juga bagaimana elektronik word of mouth dapat mempengaruhi brand image dari produk smartphone samsung. Maka penelitian ini bermaksud untuk menguji pengaruh elektronik word of mouth pada purchase intention, serta pengaruh brand image pada purchase intention produk smartphone Samsung.

\section{Word of Mouth (WOM)}

WOM diartikan sebagai komunikasi informal dari orang ke orang antara seorang komunikator non-komersial dengan penerima pesanmengenai sebuah merek, produk, organisasi, atau jasa (Harrison-Walker, 2001). Konsumen sering menggunakan WOM ketika mereka mencari informasi mengenai suatu merek, produk atau jasa dan organisasi. Selama ini, pengaruh interpersonal dan WOM telah dianggap sebagai sumber informasi yang paling penting ketika konsumen membuat keputusan pembelian (Litvin et al., 2006). Karena sumber pribadi dianggap lebih kredible daripada pemasar atau 
sumber komersial, WOM sering lebih efektif daripada media massa tradisional atau iklan dalam mengubah sikap dan perilaku konsumen. Penelitian dari Herr et al. (1991) dan Gilly et al. (1998) membuktikan bahwa WOM memberikan efek lebih besar dalam mempengaruhi keputusan pemilihan produk oleh konsumen daripada komunikasi pemasaran tradisional seperti halnya iklan. Hal tersebut juga diperkuat oleh penelitian yang dilakukan oleh Goldsmith dan Horowitz (2006) yang menemukan bahwa WOM memiliki pengaruh yang lebih besar terhhhadap perilaku konsumen daripada penjualan secara personal, iklan media cetak, dan radio.

Menurut Kotler dan Armstrong (2008), wort of mouth adalah komunikasi pribadi tentang suatu produk antara target pembeli dengan tetangganya, temannya, anggota keluarganya, dan orang-orang yang dia kenal. Komunikasi wort of mouth mengacu pada pertukaran komentar, pemikiran, atau ide antara dua konsumen atau lebih, dimana mereka bukan merupakan pemasar resmi dari perusahaan. Informasi yang didapatkan dari wort of mouth lebih jelas dan mudah dimengerti oleh konsumen karena pesan dalam informasi tersebut berasal langsung dari orang yang mempunyai pengalaman. Definisi lain dari word of mouth adalah ketika orang yang saling mengenal secara pribadi, berkomunikasi tentang produk, merek, atau jasa (Romaniuk, 2007).

\section{Elektronik Word of Mouth}

Seiring dengan perkembangan teknologi yang begitu cepat, semakin banyak konsumen yang menggunakan internet sebagai alat untuk mencari informasi mengenai suatu produk tertentu. Munculnya internet telah memungkinkan konsumen untuk berinteraksi satu sama lain dengan cepat dan mudah dan juga telah mendirikan fenomena yang dikenal sebagai pengaruh interpersonal online atau elektronik word of mouth (Brown, Broderick, dan Lee, 2007; Goldenberg, Libai dan Muller, 2001). Menurut Henning-Thurau et al, (2004) mendefinisikan elektronik word of mouth sebagai pernyataan positif atau negatif yang dibuat oleh pelanggan, aktual, atau mantan pelanggan tentang suatu produk atau perusahaan, yang dibuat untuk banyak orang dan lembaga melalui internet.

\section{WOM Tradisional vs e-WOM}

Dulunya komunikasi dari mulut ke mulut (WOM) hanya dapat dilakukan secara langsung atau tatap muka antara komunikator dengan penerima pesan. Namun seiring dengan perkembangan teknologi informasi yang semakin canggih dalam beberapa tahun belakangan ini, kini komunikasi Word of Mouth tidak hanya 
dilakukan secara tatap muka. Munculnya internet telah memungkinkan konsumen untuk berinteraksi satu sama lain dengan cepat, mudah dan murah.

Menurut Bickart dan Schindler (2010) komunikasi word of mouth biasanya terdiri dari kata-kata yang diucapkan dan dipertukarkan dengan salah sorang teman atau kerabat dalam situasi tatap muka. Berbeda dengan elektronik word of mouth yang melibatkan pengalaman-pengalaman dan opini-opini pribadi yang ditransmisikan melalui kata-kata yang tertulis. Kedua komunikasi word of mouth tersebut memiliki kelemahan dan keuntungan masing-masing. Selain itu, dibandingkan dengan word of mouthtradisional, elektronik word of mouth menjadi lebih berpengaruh karena kecepatannya, kenyamanannya, jangkauannya, dan karena ketiadaan tekanan tatap muka (Phelps at al., 2004). Dengan keunggulan yang dimiliki elektronik word of mouth masyarakat cenderung menggunakan media tersebut untuk dijadikan dasar dari suatu pembelian karena informasi yang dapat diperoleh dari elektronik word of mouth lebih mudah untuk didapatkan. Tidak lupa hal tersebut juga didukung oleh fasilitas internet yang membuat konsumen dapat mencari informasi dalam jangkauan yang lebih luas.

\section{Brand Image}

Meenaghan (1995) dalam Chen et al, (2012) mengartikan citra merek sebagai pengetahuan produk yang memungkinkan konsumen untuk mengidentifikasi suatu merek tertentu. Para pembeli mungkin mempunyai tanggapan yang berbeda terhadap citra merek perusahaan atau citra merek produk. Citra merek yang efektif akan berpengaruh pada pemantapan karakter produk dan usulan nilai, menyampaikan karakter itu dengan cara yang berbeda dengan pesaing, dan memberikan kekuatan emosional yang lebih dari sekedar citra mental.

Citra merek yang kuat merupakan hal yang sangat penting untuk membedakan produk dari pesaing. Menurut Kotler dan Keller (2012) citra merek adalah presepsi dan kepercayaan yang dipegang oleh konsumen, sebagaimana tercermin dalam asosiasi yang ada di ingatan para konsumen.

\section{Purchase Intention}

Dalam suatu kegiatan promosi yang dilakukan oleh perusahaan, apakah suatu usaha promosi tersebut sudah optimal atau belum dapat terlihat dari perilaku konsumen dengan keinginan mencari suatu informasi mengenai produk yang ditawarkan. Minat beli adalah konsumen terdorong untuk mencari suatu informasi mengenai inovasi (Kotler, 2002). 
Menurut (Schiffman dan Kanuk, 2009) di dalam penelitiannya ditemukan bahwa setelah nilai yang dirasakan sudah tercipta oleh konsumen, minat beli dari konsumen seringkali bergantung pada manfaat dan nilai yang mereka dapatkan. Grewan et al, (1998) dalam Chen et al, (2012) mengartikan minat beli sebagai kemungkinan konsumen untuk membeli suatu produk. Minat beli yang lebih besar akan meningkatkan kemungkinan pembelian.

\section{Hipotesis}

Bambauer-Sachse dan Mangold (2011) dalam Jalilvand dan Samiei (2012) menjelaskan bahwa ulasan produk yang negatif di internet, yaitu salah satu jenis komunikasi word of mouth, berpengaruh pada ekuitas merek.

Saat ini peran word of mouth sangatlah penting bagi konsumen karena dapat memberikan referensi untuk proses pengambilan keputusan pembelian mereka. Beberapa studi mengindikasikan bahwa pesan dari elektronik word of mouth merupakan sarana yang penting bagi konsumen, karena konsumen dapat mendapatkan informasi mengenai kualitas produk dan jasa (Chevalier dan Mayzlin, 2006). Oleh karena itu berdasarakan pemahaman tersebut minat beli konsumen akan dipengaruhi oleh elektronik word of mouth, dengan hipotesis sebagai berikut:

H1 : Pengaruh Elektronik Word of Mouth terhadap purchase intention.

Selain itu menurut Dolich dalam Bian dan Moutinho (2011) brand image merupakan hal yang penting karena brand image memberikan kontribusi bagi konsumen dalam memutuskan apakah merek tersebut benar-benar cocok dengan mereka atau tidak. Berdasakan pemahaman tersebut minat beli konsumen akan dipengaruhi oleh brand image, dengan hipotesis sebagai berikut:

H2 : Pengaruh Brand Image terhadap purchase intention.

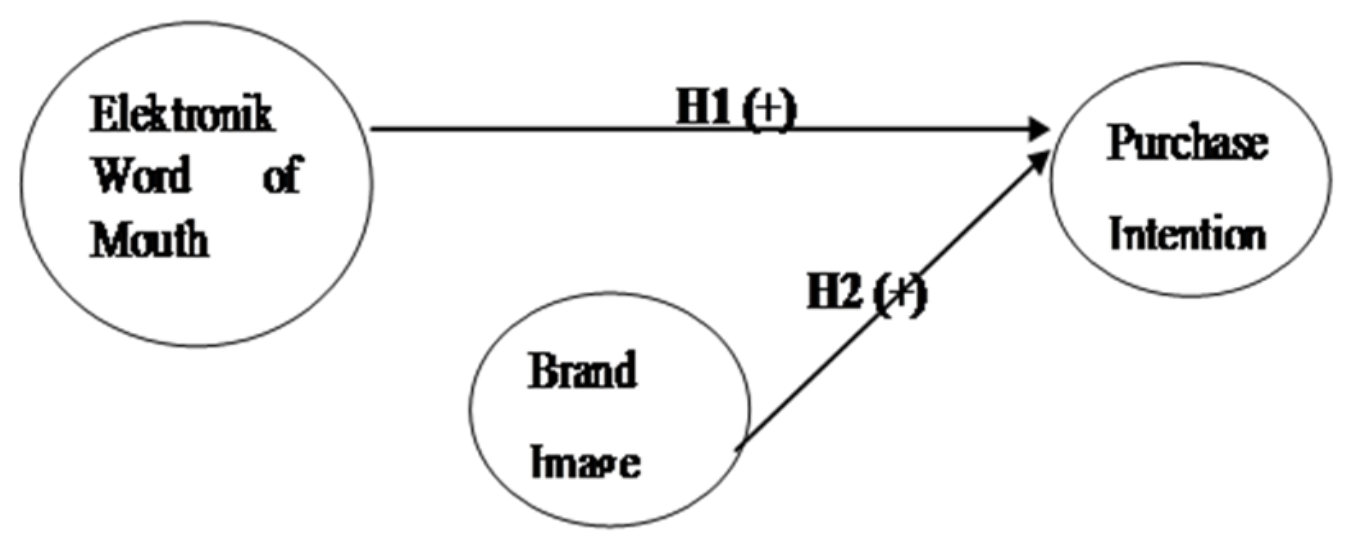




\section{Metodologi Penelitian}

Ditinjau dari tujuannya, penelitian ini di kategorikan kedalampenelitian pengujian hipotesis. Sedangkan pendekatan yang digunakan adalah pendekatan kuantitatif, yaitu pendekatan yang dilakukan dalam penelitian dengan cara menggunakan pertanyaan yang standar dan terdapat jawaban yang sudah tersedia dalam kuesioner yang dibagikan kepada responden penelitian (Hair et al., 2006)

Berdasarkan dimensi waktu, penelitian ini dikategorikan kedalam penelitian cross-section artinya hanya mengmbil data penelitian padasatu kurun waktu tertentu, mungkin selama periode harian mingguan ataubulanan dalam rangka menjawab pertanyaan penelitian (Sekaran, 2003:135). Dalam penelitian ini, peneliti menyebarkan kuesioner kepada mahasiswa S1 di Fakultas Ekonomi Universitas Negeri Yogyakarta.

\section{Metode Pengumpulan Data}

Metode pengumpulan data yang digunakan dalam penelitian ini adalah dengan mengumpulkan data primer dan sekunder. Data primer adalah informasi mengenai variabel untuk tujuan khusus dari suatu studi dimana peneliti merupakan orang pertama yang mendapatkan informasi tersebut (Sekaran dan Bougie, 2009, h. 180). Dalam penelitian ini data primer didapatkan melalui survei dengan menggunakan kuesioner. Kuesioner menggunakan metode selfadministered survey, yaitu responden diminta membaca dan menjawab sendiri pertanyaan yang terdapat dalam kuesioner sesuai dengan petunjuk yang telah diberikan sesuai dengan petunjuk. (Hair et al., 2006). Jenis kuesioner yang digunakan dalam penelitian ini adalah pertanyaan tertutup. Sementara menurut Sekaran dan Bougie (2009, h. 180) data sekunder merupakan informasi yang didapatkan dari sumber yang sudah ada atau sudah tersedia. Penelitian ini menggunakan data sekunder yang berasal dari buku-buku pustaka dan juga sumber-sumber referensi dari internet khususnya mengenai data top brand index smartphone.

\section{Metode Pengambilan Sampel}

Dalam penelitian ini, peneliti mengambil sampel 100 mahasiswa S1 Fakultas Ekonomi Universitas Negeri Yogyakarta, yang menggunakan smartphone Samsung yang berbasis android. Pengambilan sampel dalam penelitian ini menggunakan nonprobability sampling.

\section{Variabel Penelitian dan Definisi} Operasional

Dalam penelitian ini terdapat dua variabel independen dan satu variabel dependen. Dengan rincian variabel Purchase Intention sebagai variabel 
dependen kemudian eWOM dan Brand Image sebagai variabel independen. Setiap variabel dalam penelitian ini akan diukur dengan item-item tertentu.

Menurut Henning-Thurau et al. (2004) mendefinisikan elektronik word of mouth sebagai pernyataan positif atau negatif yang dibuat oleh pelanggan potensial, aktual, mantan pelanggan tentang suatu produk atau perusahaan yang dibuat tersedia untuk banyak orang dan lembaga melalui internet. Untuk mengukur variabel elektronik word of mouth digunakan enam item yang diadopsikan dari Bambauer-Sachse dan Mangold (2011). Meenaghan (1995) dalam
Chen et al., (2012) mengartikan brand image sebagai pengetahuan produk yang memungkinkan konsumen untuk mengidentifikasi suatu merek tertentu. Untuk mengukur variabel brand image digunakan tiga item yang diadopsikan dari Davis et al. (2009). Grewan et al., (1998) dalam Chen et al., (2012) mengartikan purchase intention sebagai kemungkinan konsumen untuk membeli suatu produk dan dalam penelitian ini digunakan tiga item untuk mengukur minat beli yang diadopsikan dari Schlosser et al., (2006). Untuk lebih jelasnya, definisi operasional ketiga variabel tersebut dijelaskan pada Tabel 3.1.

Tabel 3.1

Variabel Penelitian dan Devinisi Operasional

\begin{tabular}{|c|c|}
\hline Variabel & Item \\
\hline \multirow{8}{*}{$\begin{array}{l}\text { Elektronik } \\
\text { Word of Mouth } \\
\text { (Bambauer- } \\
\text { Sachse dan } \\
\text { Mangold, 2011) }\end{array}$} & Saya sering membaca ulasan produk di internet yang dituliskan \\
\hline & $\begin{array}{l}\text { oleh konsumen untuk mengetahui produk atau merek apa yang } \\
\text { memberikan kesan baik. }\end{array}$ \\
\hline & Saya sering membaca ulasan produk di internet yang ditulis oleh \\
\hline & $\begin{array}{l}\text { konsumen untuk memastikan saya membeli produk atau merek } \\
\text { yang tepat. }\end{array}$ \\
\hline & $\begin{array}{l}\text { Saya sering berkonsultasi dengan ulasan produk di internet yang } \\
\text { ditulis oleh konsumen untuk membentuk memilih produk atau } \\
\text { merek yang tepat. }\end{array}$ \\
\hline & $\begin{array}{l}\text { Saya sering mengumpulkan informasi dari ulasan produk di } \\
\text { internet yang ditulis oleh konsumen sebelum saya membeli } \\
\text { produk atau merek tertentu. }\end{array}$ \\
\hline & $\begin{array}{l}\text { Apabila saya tidak membaca ulasan produk di internet yang } \\
\text { ditulis oleh konsumen ketika saya akan membeli produk atau } \\
\text { merek, saya akan cemas atas keputusan saya. }\end{array}$ \\
\hline & $\begin{array}{l}\text { Ketika saya membeli suatu produk atau merek, ulasan produk di } \\
\text { internet yang ditulis oleh konsumen membuat saya yakin dan } \\
\text { percaya diri atas pembelian yang dilakukan. }\end{array}$ \\
\hline \multirow{4}{*}{$\begin{array}{l}\text { Brand Image } \\
\text { (Davis et al., } \\
\text { 2009) }\end{array}$} & Dibandingkan dengan produk atau merek lain, produk atau \\
\hline & \\
\hline & Produk atau merek ini mempunyai sejarah yang panjang. \\
\hline & $\begin{array}{l}\text { Konsumen dapat memprediksi bagaimana produk atau merek ini } \\
\text { akan berfungsi. }\end{array}$ \\
\hline
\end{tabular}


Purchase Kemungkinan saya untuk membeli merek ini besar.

Intention Saya cenderung akan membeli merek ini.

(Schlosser et al., Saya mempunyai niat yang kuat untuk membeli merek ini. 2006)

\section{Karakteristik Obyek Penelitian}

Obyek penelitian dalam penelitian ini adalah mahasiswa S1 Fakultas Ekonomi Universitas Negeri Yogyakarta yang menggunakan smartphone Samsung yang berbasis android dan setidaknya mahasiswa tersebut dalam jangka waktu satu bulan ini mengakses internet dan sosial media. Pengelompokan karakteristik obyek penelitian didasarkan pada faktor demografi yang meliputi usia, jenis kelamin, dan uang saku per bulan. Untuk kategori jenis kelamin peneliti membagi menjadi dua kelompok, yaitu laki-laki dan perempuan. Selain itu peneliti juga mengelompokkan karakteristik obyek penelitian berdasarkan pendapatan atau uang saku rata-rata per bulan, dimulai dari < Rp500.000,00,-, Rp500.000,00Rp1.000.000,00,-, dan > Rp1.000.000,00,-, angkatan kuliah responden, responden memiliki smartphone atau tidak.

\section{Metode Analisis Data}

Metode analisis yang digunakan dalam penelitian ini meliputi metode deskriptif dan metode deskriptif dan metode inferensial. Metode deskriptif digunakan untuk mendeskripsikan atau menjelaskan identitas responden dan varabel penelitian. Sedangkan metode inferensial digunakan untuk menguji hipotesis, dan menggunakan alat bantu SPSS versi 22. Teknik analisis yang akan dilakukan dalam penelitian ini adalah regresi berganda. Dalam penelitian ini regresi berganda diterapkan dengan variabel elektronik word of mouth dan brand image terhadap purchase intention suatu produk.

\section{Uji Validitas}

Validitas berarti instrumen yang digunakan dapat mengukur apa yang akan diukur (Ferdinand, 2006). Validitas yang digunakan dalam penelitian ini, yaitu validitas isi, menggambarkan kesesuaian sebuah pengukur data dengan apa yang akan diukur (Ferdinand, 2006). Uji validitas digunakan untuk mengetahui sah atau tidaknya suatu kuesioner. Selanjutnya peneliti akan melakukan pengujian face validity, yang bertujuan untuk mengukur suatu konsep terlihat telah mampu mengungkap konsep yang telah diukur. Setelah itu peneliti akan melakukan pengujian validitas konstruk yaitu validitas yang menunjukkan seberapa baik hasil yang diperoleh dari pengukuran yang sesuai dengan teori yang mendasari desain pengujian. Menurut Sekaran (2010) validitas konstruk merupakan 
kemampuan ketetapan suatu alat ukur yang digunakan sesuai dengan landasan teori yang dikembangkan dalam desain penelitian. Uji validitas dilakukan dengan metode Confirmatory Factor Analysis. Dalam metode Confirmatory Faktor Analysis, kriteria yang digunakan adalah nilai factorloading. Hair et al., (2006) menjelaskan kriteria factor loadingdikatakan valid adalah jika lebih besar dari 0,50.

\section{Uji Reliabilitas}

Uji reabilitas bertujuan untuk menunjukkan sejauh mana alat pengukur yang digunakan dalam penelitian dapat dipercaya atau dapat diandalkan selain itu juga bila diadakan pengukuran secara berulang kali tetap bisa memberikan pengukuran yang relatif konsisten. Uji reabilitas pada penelitian ini menggunakan uji statistic Cronbach Alpha (a). Semakin koefisien Cronbach Alpha mendekati 1, maka semakin tinggi pula konsistensi dan stabilitas dari item alat ukur yang digunakan sehingga item tersebut memiliki tingkat konsistensi dan stabilitas yang baik dan dapat dipercaya. Menurut Hair et al., (2006) kriteria kuesioner dinyatakan reliabel adalah jika nilai koefisien Cronbach-Alpha lebih besar dari 0,60.

\section{Uji Hipotesis}

Hipotesis dalam penelitian ini diuji menggunakan dua tahap analisis regresi. Tahap pertama adalah melakukan analisis regresi sederhana untuk menguji hipotesis pertama, yaitu mengetahui pengaruh dari elektronik word of mouth dan brand image terhadap purchase intention suatu produk. Tahap kedua adalah melakukan analisis regresi berganda untuk menguji hipotesis kedua dan ketiga, yaitu mengetahui pengaruh dari purchase intention terhadap brand image dan word of mouth pada konsumen smartphone Samsung berbasis android.

\section{Hasil dan Pembahasan}

Dalam penelitian ini, analisis data dilakukan secara deskriptif dan inferensial. Untuk mendeskripsikan informasi mengenai responden, peneliti menggunakan analisis inferensial. Selain itu dalam bab ini peneliti juga menyajikan uji validitas dan uji reliabilitas terhadap instrumen atau kuesioner yang digunakan dalam penelitian ini. Data dari kuesioner ini didapatkan dengan menggunakan kuesioner yang dikumpulkan pada 29 April 2014 sampai dengan 2 Mei 2014. Peneliti menyebarkan kuesioner sebanyak 100 dan terkumpul dengan jumlah yang sama. Lalu data tersebut diproses dengan jumlah 100 responden.

Uji validitas terhadap variabel dan item penelitian ini menggunakan teknik analisis factor (confirmatory factor 
analysis). Uji validitas ini menggunakan program statistik SPSS versi 22 dengan metode rotasi faktor varimax. Tingkat signifikansi validitas suatu item penelitian dapat dinilai dari nilai factor loading item tersebut yang memiliki nilai koefisien lebih besar dari 0,50.

Tabel 4.4.

Hasil Uji Validitas : Rotated Component Matrix

\begin{tabular}{|c|c|c|}
\hline & Rotated Component & \\
\hline & 1 & 3 \\
\hline EWOM 1 & 0,712 & \\
\hline EWOM 2 & 0,783 & \\
\hline EWOM 3 & 0,884 & \\
\hline EWOM 4 & 0,850 & \\
\hline EWOM 5 & 0,784 & \\
\hline EWOM 6 & 0,727 & \\
\hline BI 1 & & 0,748 \\
\hline BI 2 & & 0,763 \\
\hline BI 3 & & 0,695 \\
\hline PI 1 & & \\
\hline PI 2 & & \\
\hline PI 3 & & \\
\hline Sumb & Primer, 2014; EWOM = & tronik Word of Mouth; BI = Brand Image; PI \\
\hline$=$ Purchase & & \\
\hline Berda & hasil confirmatory & item-iten pernyataan tersebut valid. \\
\hline factor analy & yang disajikan dalam & Komponen faktor 2 terdiri atas item-item \\
\hline Tabel $4.4 \mathrm{di}$ & ka komponen faktor 1 & pertanyaan yang terdapat dalam \\
\hline terdiri atas & m pertanyaan yang & instrumen Purchase Intention (PI 1, PI 2, PI \\
\hline terdapat d & istrumen Elektronik & 3). Oleh karena masing-masing item \\
\hline Word of $\mathrm{N}$ & WOM 1, EWOM 2, & memiliki bobot faktor (factor loading) lebih \\
\hline EWOM 3, E & EWOM 5, EWOM 6). & besar dari 0,50 , maka dapat disimpulkan \\
\hline Oleh karena & masing item memiliki & bahwa item-iten pernyataan tersebut \\
\hline bobot fakto & loading) lebih besar & valid.Berdasarkan hasil confirmatory \\
\hline dari $0,50, m$ & it disimpulkan bahwa & factor analysis yang telah dilakukan, maka \\
\hline item-iten & an tersebut valid. & dapat disimpulkan bahwa item-item \\
\hline Komponen & terdiri atas item-item & pernyataan yang terdapat \\
\hline pertanyaan & terdapat dalam & instrumen penelitian ini layak digunakan \\
\hline instrumen $\mathrm{I}$ & ge (BI 1, BI 2, BI 3). & untuk tahap berikutnya pada pengujian \\
\hline Oleh karena & masing item memiliki & hipotesis. \\
\hline
\end{tabular}

bobot faktor (factor loading) lebih besar

Uji Reliabilitas

dari 0,50, maka dapat disimpulkan bahwa 
Proses analisis pengujian instrumen selanjutnya adalah uji reliabilitas. Uji ini menggunakan alat bantu statistik yaitu SPSS versi 22. Item dan variabel yang reliabel ditunjukkan melalui koefisien Cronbach's Alpha yang lebih besar dari 0,60 (Hair et al., 2010).

Tabel 4.5.

Hasil Uji Reliabilitas

\begin{tabular}{lll}
\hline Variabel & Alpha-Cronbach & Reliabilitas \\
\hline EWOM 1 & & \\
EWOM 2 & & \\
EWOM 3 & 0,895 & Reliabel \\
EWOM 4 & & \\
EWOM 5 & & \\
EWOM 6 & & Reliabel \\
BI 1 & 0,617 & \\
BI 2 & & Reliabel \\
BI 3 & & \\
PI 1 & 0,672 & \\
PI 2 & & \\
PI 3 & &
\end{tabular}

Berdasarkan data yang disajikan data Tabel 4.5 di atas, menunjukkan bahwa masing-masing instrumen memiliki nilai koefisien reliabilitas Alpha-Cronbach lebih besar dari nilai cut-off yaitu 0,60. Dengan demikian dapat disimpulkan bahwa, masing-masing instrumen penelitian ini reliabel atau handal sehingga layak digunakan pada tahap berikutnya yaitu pengujian hipotesis.

\section{Analisis Regresi Linier Berganda}

Regresi linier berganda digunakan untuk menguji pengaruh lebih dari satu independent variabel terhadap dependent variabel dan variabel control. Hasil analisis regresi linier berganda disajikan dalam Tabel 4.7 berikut ini.

Tabel 4.7.

Analisis Regresi

\begin{tabular}{lllll}
\hline Variabel & Tahap 1 & Tahap 2 & Tahap 3 & Tahap 4 \\
\hline Usia & 0,021 & $-0,017$ & $-0,050$ & $-0,070$ \\
Jenis Kelamin & 0,049 & 0,135 & 0,089 & 0,156 \\
Uang Saku & $-0,040$ & 0,026 & $-0,058$ & 0,002 \\
EWOM & - & 0,382 & - & $\mathbf{0 , 3 2 7}$ \\
BI & - & - & 0,342 & $\mathbf{0 , 2 7 8}$ \\
$\mathbf{R}^{2}$ & 0,004 & 0,135 & 0,113 & 0,208 \\
\hline \multicolumn{2}{c}{ Dependent Variabel : Purchase Intention }
\end{tabular}


Sumber : Data Primer, diolah, 2014

Berdasarkan data tabel 4.7 diatas dapat dilihat pada tabel tahap keempat menunjukkan bahwa variabel kontrol (usia, jenis kelamin dan uang saku) mempunyai pengaruh yang besar dalam pengujian hipotesis.

Pengaruh elektronik word of mouth terhadap purchase intention pada konsumen Samsung berbasis android, dapat ditunjukkan dengan nilai Beta sebesar 0,327 maka keterlibatan konsumen pada elektronik word of mouth berpengaruh positif pada purchase intention suatu produk. Sedangkan nilai $\mathrm{R}$ square sebesar 0,135 , berarti peran atau kontribusi variabel elektronik word of mouth mampu menjelaskan variabel purchase intention sebesar $13,5 \%$.

Brand image berpengaruh positif terhadap purchase intention pada konsumen Samsung berbasis android, dengan nilai Beta sebesar 0,278, dan dengan nilai $R$ square sebesar 0,109 ini berarti peran atau kontribusi variabel brand image mampu menjelaskan variabel purchase intention sebesar 10,9\%. Hal ini menunjukkan bahwa semakin kuat atau tinggi keterlibatan konsumen pada brand image, maka purchase intention cenderung akan meningkat atau semakin kuat.

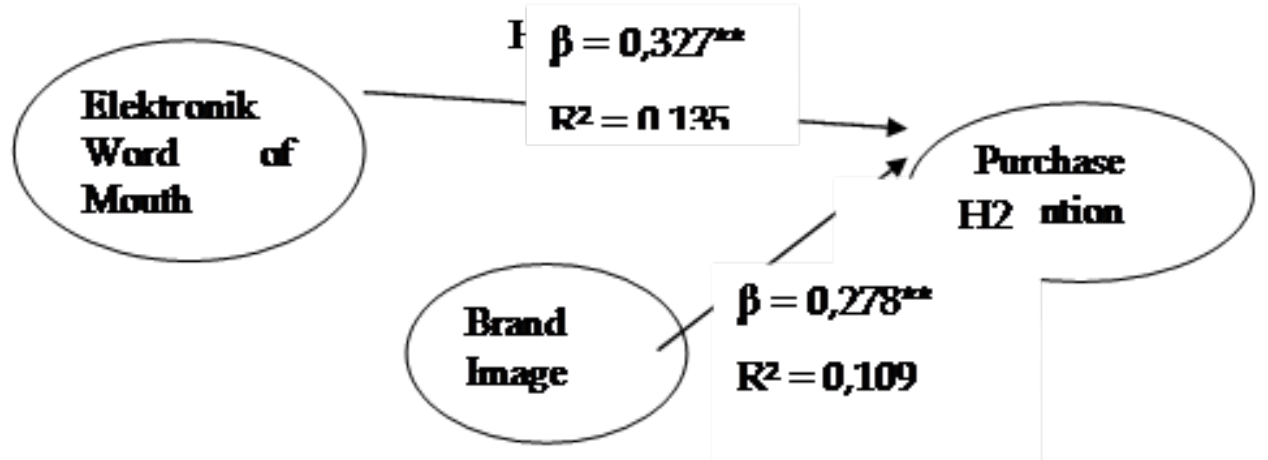

Berdasarkan hasil Tabel 4.7 diketahui hasil dari hipotesis pertama menunjukkan bahwa meningkatnya keterlibatan konsumen pada elektronik word of mouth memiliki nilai Beta sebesar 0,327 , dan dengan probabilitas signifikansi 0,001. Hal tersebut dapat diartikan bahwa keterlibatan konsumen pada elektronik word of mouth berpengaruh positif pada purchase intention suatu produk. Dalam Chatterjee (2001) juga mengatakan bahwa jenis pesan ini (EWOM) dapat secara efektif mengurangi resiko yang disadari oleh konsumen ketika membeli suatu produk atau jasa, sehingga minat beli dan pengambilan keputusan mereka dapat 
dipengaruhi lebih jauh lagi. Minat beli konsumen atas suatu produk khususnya produk Samsung berbasis android, akan semakin meningkat jika konsumen mempunyai keterlibatan yang besar pada elektronik word of mouth. Misalnya dengan cara memberikan komentar suatu pada suatu situs yang menjual produk Samsung berbasis android yang membuat orang lain tertarik pada produk tersebut.

Dalam Tabel 4.8 dapat dilihat juga hasil dari hipotesis kedua penelitian ini terbukti menyatakan brand image berpengaruh positif terhadap purchase intention dengan nilai Beta sebesar 0,278, dan dengan probabilitas signifikansi 0,01 atau 99\%. Hal ini menunjukkan bahwa semakin kuat atau tinggi keterlibatan konsumen pada brand image, maka purchase intention cenderung akan meningkat atau semakin kuat.

\section{Kesimpulan}

Berdasarkan pengujian terhadap hipotesis penelitian ini terdapat beberapa kesimpulan yang dapat diambil. Sesuai dengan hipotesis penelitian yang pertama, dapat ditarik kesimpulan bahwa variabel elektronik word of mouth berpengaruh positif terhadap variabel purchase intention. Hal ini menunjukkan bahwa semakin tinggi tingkat keterlibatan terhadap elektronik word of mouth, maka purchase intention pada suatu merek yang bersangkutan akan semakin meningkat.
Kesimpulan kedua yang dapat diambil dari penelitian ini sesuai dengan hipotesis kedua yang dirumuskan adalah brand image berpengaruh positif terhadap purchase intention. Hal ini menunjukkan bahwa semakin tinggi tingkat keterlibatan terhadap brand image, maka purchase intention pada merek yang bersangkutan akan semakin kuat. Kedua kesimpulan diatas mendukung penelitian atau riset yang sudah dilakukan sebelumnya oleh Jalilvand dan Semiei (2012). Hasil dari penelitian tersebut menunjukkan bahwa elektronik word of mouth dan brand image mempunyai pengaruh pada purchase intention.

\section{Keterbatasan Peneliti}

Dalam penelitian ini, peneliti memiliki beberapa keterbatasan. Dengan adanya penyampaina keterbatasan penelitian ini, diharapkan dapat mendorong penelitian lanjutan untuk memperbaiki penelitian dan mengembangkan lebih lanjut.

Responden penelitian ini adalah seluruh mahasiswa S1 Universitas Negeri Yogyakarta yang mempunyai smartphone Samsung berbasis android saja dan tidak dapat digeneralisasikan pada populasi responden secara keseluruhan.

Penelitian ini hanya menguji variabel elektronik word of mouth, brand image, purchase intention serta variabel control seperti kelompok usia, jenis kelamin dan 
uang saku rata-rata perbulan. Sehingga penelitian selanjutnya perlu adanya penambahan variabel -variabel yang dapat menjelaskan informasi yang lebih akurat lagi.

\section{Saran}

Berdasarkan keterbatasan penelitian yang disebutkan diatas, saran yang diberikan peneliti untuk penelitian selanjutnya adalah :

Untuk penelitian selanjutnya, jumlah sampel (responden) sebaiknya ditambah, agar dapat meminimalisasi bias yang terjadi pada penelitian berikutnya.

Untuk penelitian selanjutnya, lingkup responden dapat diperluas, tidak hanya dari kalangan mahasiswa saja agar hasil penelitian dapat diaplikasikan di berbagai kalangan responden lainnya.

Untuk penelitian selanjutnya, dapat ditambah variabel lain yang dapat mempengaruhi dan menjelaskan variabel purchase intention agar dapat diaplikasikan secara lebih komprehensif bagi pemasar atau produsen perusahaan.

\section{DAFTAR PUSTAKA}

Adjie, M.T., Noble, S.M., dan Noble, C.H. (2009), “The Influence of C2C Communities On Customer Purchase Behavior", Journal of the Academy of Marketing Science, Vol. 38 No. 5, pp. 635653.
Bambauer-Sachse, S. dan Mangold, S. (2011), "Brand Equity Dilution Through Negative Online Word-of-Mouth Communication", Journal of Retailing and Consumer Services, Vol. 18, pp. 38-45.

Bian, X. dan Moutinho, L. (2011), "The Role of Brand Image, Product Involvement, and Knowledge In Explaining Consumer Purchase Behaviour of Counterfeits: Direct and Indirect Effects", European Journal of Marketing, Vol. 45 Nos 1/2, p. 191.

Bickart, B. dan Schindler, R.M. (2001), “Internet Forums As Influential Sources of Consumer Information", Journal of Interactive Marketing, Vol. 15 No. 3, pp. 31-40.

Brown, J., Broderick, A.J. dan Lee, N. (2007), “Word of Mouth Communication Within Online Commuities: Conseptualizing the online Sosial Network", Journal of Interacttive Marketing, Vol. 21 No. 3, pp. 2-20.

Chatterjee, P. (2001), “Online Reviews: Do Consumers Use Them?", Advances in Consumers Research, Vol. 28 No. 1, pp. 129-133.

Chen, C. C., Chen, P.K., dan Huang, C. E. (2012), "Brand and Consumer Behavior", Social Behavior and Personality, Vol. 40 No. 1, pp. 105-114.

Chevalier, J.A. dan Mayzlin, D. (2006), "The Effect of Word of Mouth on Sales: Online Book Reviews", Journal of 
Marketing Research, Vol. 43 No. 3 pp. 345354.

Davis, D.F., Golicic, S.L. dan Marquardt, A. (2009), “Measuring Brand Equity for Logistics Services", International Journal of Logistics Management, Vol. 20 No. 2, pp. 201-212.

Hennig-Thurau, T.,Gwinner, K.P., Walsh, G. dan Gremler, D.D. (2004), Electronic Word of Mouth via Consumer Opinion Platforms: What Motivates Consumer to Articulate Themselves On the Internet", Jurnal of Interactive Marketing, Vol. 18 No. 1, pp. 38-52.

Jalilvand, M. R. dan Samiei, N. (2002), "The Effect of Electronic Word of Mouth On Brand Image and Purchase Intention : An Empirical Study in the Automobile Industry in Iran", Marketing Intelligence $\mathcal{E}$ Planning. Vol. 30 Iss: 4 pp. 460-476.

Jalilvand, M. R. dan Samiei, N. (2002), “The Impact of Electronic Word of Mouth On A Tourism Destination Choice: Testing the Theory of Planned Behavior
(TPB)", Internet Research, Vol. 22 Iss: 5 pp. 591-612.

Keller, K. L. (2008) Strategic Brand Management 3rd ed., Upper Saddle River, NJ: Prentice Hall.

Kotler. P. dan Amstrong, P. (2008), "Principles of Marketing 12th ed., New Jersey: Pearson Prentice Hall.

Kotler, P. dan Keller, K.L. (2009), Marketing Management 14th ed., Upper Saddle River, New Jersey: Person Pretice Hall.

Romaniuk, J. (2007), “Word of Mouth and Viewing of Television Programs", Journal of Advertising. Vol. 47 No. 3.

Schiffman, L.G. dan Kanuk, L.L. (2009), Consumer Behavior 10th ed., Englewood Cliffs, NJ: Prentice-Hall.

Sekaran, U. dan Roger Bougie. (2009), Research Methods for Business: A Skill Building Approach 5th ed., West Sussex: John Wiley and Sons Ltd.

www.topbrand-award.com diakses pada April 2014

www.wikipedia.com diakses pada April 2014 